\title{
PEMBERIAN MASSAGE EFFLEURAGE PADA PASIEN HIPERTENSI DI DESA SRIBAWONO LAMPUNG TIMUR
}

https: / /doi.org/10.33024/jkpm.v4i6.2861

\author{
Eka Yudha Chrisanto ${ }^{1}$, Susi Anisia Laila², Rahma Elliya ${ }^{3^{*}}$ \\ ${ }^{1,2,3}$ Program Studi Ilmu Keperawatan Universitas Malahayati \\ Disubmit: 17 Juni 2021 Diterima: 01 Desember 2021 Diterbitkan: 02 Desember 2021 \\ Email Korespondensi: rahma@gmail.com
}

\begin{abstract}
ABSTRAK
Badan Kesehatan Dunia (WHO) menyebutkan jumlah penderita hipertensi akan terus meningkat seiring dengan jumlah penduduk yang bertambah pada 2025 mendatang diperkirakan sekitar $29 \%$ warga dunia terkena hipertensi. Untuk membuat tubuh menjadi rileks dapat dilakukan dengan beberapa cara seperti terapi musik klasik, yoga, tehnik nafas dalam, dan terapi massage untuk menurunan hipertensi. Tujuan setelah penyuluhan dan demonstrasi, diharapkan pemberian massage effleurage dapat untuk tekanan darah pada klien hipertensi. Adapun kegiatan yang dilakukan berupa penyuluhan menggunakan leaflet dan demonstrasi massage effleurage. Terdapat penurunan tekanan darah pada klien hipertensi setelah pemberian massage effleurage selama 7 hari di Sribawono, Lampung Timur. Dengan demikian, pemberian massage effleurage pada klien hipertensi sangat efektif dalam menurunkan tekanan darah.
\end{abstract}

Kata Kunci: Massage effleurage, Hipertensi

\begin{abstract}
The World Health Organization (WHO) said the number of people with hypertension will continue to increase along with the population increasing in the next 2025 estimated that around 29\% of world citizens affected by hypertension. To make the body relaxed can be done in several ways such as classical music therapy, yoga, deep breathing techniques, and massage therapy to reduce hypertension. The purppose after counseling and demonstration, is expected to give effleurage massage for blood pressure in hypertensive's client. The activities carried out in the form of counseling using leaflets and demonstration massage effleurage. There was a decrease in blood pressure in hypertensive clients after giving effleurage massage for 7 days at Sribawono, East Lampung. Thus, giving effleurage massage to hypertensive clients is very effective in lowering blood pressure.
\end{abstract}

Keywords: Massage effleurage, hypertension 


\section{PENDAHULUAN}

Badan Kesehatan Dunia (WHO) menyebutkan jumlah penderita hipertensi akan terus meningkat seiring dengan jumlah penduduk yang bertambah pada 2025 mendatang diperkirakan sekitar 29\% warga dunia terkena hipertensi. WHO menyebutkan negara ekonomi berkembang memiliki penderita hipertensi sebesar $40 \%$ sedangkan negara maju hanya $35 \%$, kawasan Afrika memegang posisi puncak penderita hipertensi, yaitu sebesar 40\%. Kawasan Amerika sebesar 35\% dan Asia Tenggara 36\%. Kawasan Asia penyakit ini telah membunuh 1,5 juta orang setiap tahunnya. Hal ini menandakan satu dari tiga orang menderita hipertensi.Sedangkan di Indonesia cukup tinggi, yakni mencapai 32\% dari total jumlah penduduk (Widiyani, 2013; Almiyani, 2018).

Riskesdas 2018 menyatakan prevalensi hipertensi berdasarkan hasil pengukuran pada penduduk usia $\geq 18$ tahun sebesar $34,1 \%$, tertinggi di Kalimantan Selatan (44.1\%), sedangkan terendah di Papua sebesar (22,2\%). Estimasi jumlah kasus hipertensi di Indonesia sebesar 63.309.620 orang, sedangkan angka kematian di Indonesia akibat hipertensi sebesar 427.218 kematian (Riskesdas RI, 2018).

Hipertensi terjadi pada kelompok umur $31-44$ tahun $(31,6 \%)$, umur 45-54 tahun (45,3\%), umur 55-64 tahun $(55,2 \%)$. Dari prevalensi hipertensi sebesar $34,1 \%$ diketahui bahwa sebesar $8,8 \%$ terdiagnosis hipertensi dan $13,3 \%$ orang yang terdiagnosis hipertensi tidak minum obat serta $32,3 \%$ tidak rutin minum obat. Hal ini menunjukkan bahwa sebagian besar penderita Hipertensi tidak mengetahui bahwa dirinya Hipertensi sehingga tidak mendapatkan pengobatan (Riskesdas RI, 2018).

Hipertensi yang tidak mendapat penanganan yang baik menyebabkan komplikasi seperti Stroke, Penyakit Jantung Koroner, Diabetes, Gagal Ginjal dan Kebutaan. Stroke (51\%) dan Penyakit Jantung Koroner (45\%) merupakan penyebab kematian tertinggi.Kerusakan organ target akibat komplikasi Hipertensi akan tergantung kepada besarnya peningkatan tekanan darah dan lamanya kondisi tekanan darah yang tidak terdiagnosis dan tidak diobati. Organ-organ tubuh yang menjadi target antara lain otak, mata, jantung, ginjal, dan dapat juga berakibat kepada pembuluh darah arteri perifer itu sendiri. Selain itu Hipertensi banyak terjadi pada umur 35-44 tahun (6,3\%), umur 45-54 tahun (11,9\%), dan umur 55-64 tahun $(17,2 \%)$. Sedangkan menurut status ekonominya, proporsi Hipertensi terbanyak pada tingkat menengah bawah $(27,2 \%)$ dan menengah $(25,9 \%)$ (Kemenkes RI, 2019)

Menurut data Sample Registration System (SRS) Indonesia tahun 2014, Hipertensi dengan komplikasi $(5,3 \%)$ merupakan penyebab kematian nomor 5 (lima) pada semua umur. Pembiayaan Jaminan Kesehatan Nasional (JKN) Tahun 2015 menunjukkan sebanyak 1,3 juta orang atau 0,8\% peserta JKN mendapat pelayanan untuk penyakit Katastropik, yang menghabiskan biaya sebanyak 13,6 triliun rupiah atau 23,9\% yang terdiri dari; Penyakit Jantung $(11,59 \%)$, Gagal Ginjal Kronik $(4,71 \%)$, Kanker $(4,03 \%)$, Stroke $(1,95 \%)$, Thalasemia $(0,73 \%)$, Cirosis Hepatitis $(0,42 \%)$, Leukemia $(0,3 \%)$, Haemofilia (0,16\%) (Kemenkes RI, 2019).

Mengatasi hipertensi dapat dilakukan pengobatan farmakologi dan non farmakologi (Nirmawati, 2014).Pengobatan farmakologi yang diberikan pada klien adalah dengan obat, obat-obatan standar hipertensi adalah obat yang meliputi golongan diuretik, menekan simpatetik (simpatolitik), vasodilator arteriol, antagonis angiotensin (ACE inhibitor), penghambat 
saluran kalsium (blocker calsium antagonis) (Muttaqin, 2012). Penggunaan obat pada penderita hipertensi memiliki beberapa kelemahan, antara lain biaya mahal, membutuhkan kepatuha karena membutuhkan waktu yan relatif lama untuk dapat menurunkan tekanan darah serta sering timbul kebosanan mengkonsumsi obat pada pasien hipertensi (Myrank, 2009).

Asuhan keperawatan bertujuan untuk membantu penderita hipertensi dalam mempertahankan tekanan darah pada tingkat optimal dan meningkatkan kualitas kehidupan secara maksimal dengan cara memberi intervensi asuhan keperawatan, sehingga dapat terjadi perbaikan kondisi kesehatan. Salah satu tindakan yang dapat diberikan untuk menurunkan tekanan darah pada penderita hipertensi adalah menggunakan massase (Izzo, 2008., Saferi, 2013).

Sejumlah studi menunjukkan bahwa terapi masase/pijat yang dilakukan secara teratur dapat menurunkan tekanan darah sistolik dan diastolik, menurunkan kadar hormone stress cortisol, menurunkan kecemasan sehingga tekanan darah akan turun dan fungsi tubuh semakin membaik (Wahyuni, 2014). Dalam masase terdapat banyak manipulasi/teknik yang bisa dilakukan, salah satu teknik yang paling umum dan mudah dilakukan yaitu teknik effleurage.Manipulasi effleurage merupakan manipulasi pokok dalam sport masase. Tujuan manipulasi effleurage adalah memperlancar peredaran darah, cairan getah bening dan apabila dilakukan dengan tekanan yang lembut akan memberikan efek penenangan, (Arovah, 2012; Ananto, 2017). Sedangkan Priyonoadi (2011; Ananto, 2017) juga menjelaskan tujuan dari manipulasi effleurage yaitu untuk membantu melancarkan peredaran darah dan cairan getah bening (cairan limpha), yaitu membantu mengalirkan darah di pembuluh balik (darah veneus) agar cepat kembali ke jantung.

\section{MASALAH}

Alasan saya memilih tempat penyuluhan kesehatan tentang Hipertensi dan demontrasi tentang pemberian massage effleurage di Sribawono Lampung Timur ialah karena keluarga saya sendiri memiliki masalah kesehatan hipertensi. dimana tujuan umum dalam kegiatan diharapkan pemberian massage effleurage dapat menurunkan tekanan darah pada klien hipertensi. Dan tujuan khusus dalam kegiatan yaitu asuhan keperawatan, telaah jurnal untuk menentukan intervensi, evaluasi hasil aplikasi intervensi, perbandingan hasil intervensi pemberian massage effleurage.

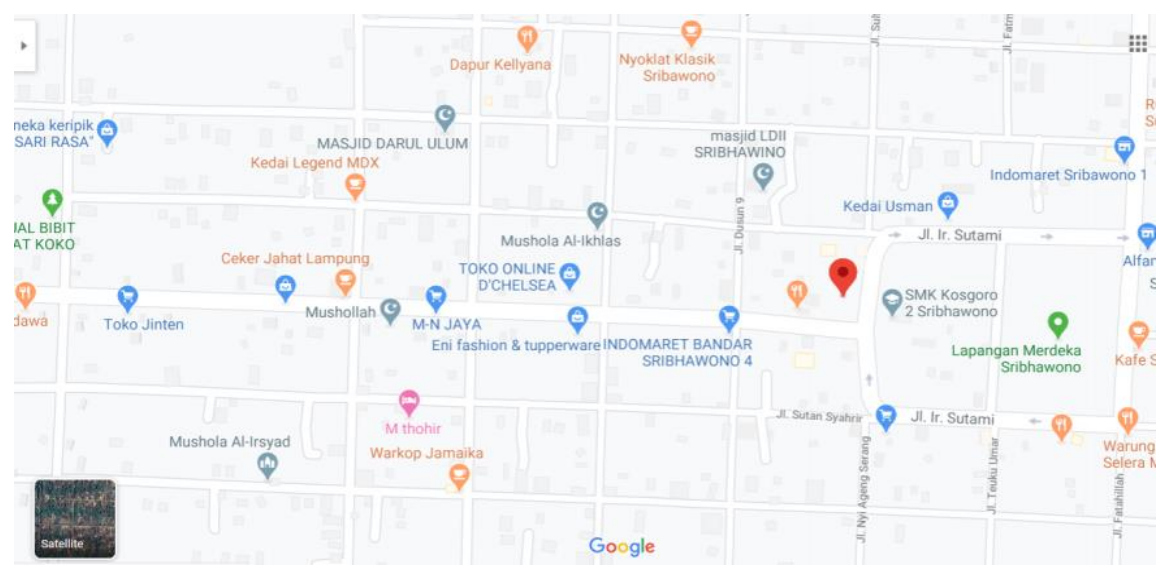

Gambar 2.1 Lokasi penyuluhan dan demonstrasi 


\section{METODE}

1) Tujuan Persiapan

Tahap persiapan dari kegiatan adalah pembuatan pre planning, persiapan penyajian leaflet dan demostrasi, tempat dan alat-alat lainnya disiapkan oleh peneliti. Pembuatan leaflet dibuat pada hari selasa 04 Mei 2020, pada tanggal 05 Mei 2020 dilakukan penyuluhan, pengecekan tekanan darah, dan demostrasi massage effleurage.

2) Tahap Pelaksanaan

Kegiatan ini dengan pemberitahuan kepada klien. Dan dilanjutkan penyuluhan penyuluhan, pengecekan tekanan darah, dan demostrasi massage effleurage.

3) Evaluasi

a. Struktur

Peserta hadir 1 orang yaitu perempuan. Setting tempat sudah sesuai dengan rencana dan perlengkapan yang dilakukan untuk penyuluhan sudah tersedia dan sudah digunakan sebagaimana mestinya. Peran peneliti sebagai modertor, notulen, observer, dan juga fasilitator. Penggunaan bahasa yang dipraktekkan sudah komunikatif dalam penyampaianya, klien dapat memahami dan dapat mempraktekkan kembali yang di demonstrasikan.

b. Proses

Pelaksanaan kegiatan dilaksanakan pukul $09.00 \mathrm{~s} / \mathrm{d} 09.30$ WIB. Sesuai dengan jadwal yang sudah ditentukan.

\section{HASIL DAN PEMBAHASAN}

Pelaksanaan pemberian terapi massage effleurage dilaksanakan pada tanggal 05 Mei 2020 s/d 11 Mei 2020. Penelitian dilakukan selama 7 hari, setelah dilakukan nya pemberian terapi selama 7 hari menurunkan tekanan darah klien. Berikut gambar pelaksanaan penyuluhan, pengecekan tekanan darah dan pemberian terapi massage effleurage:
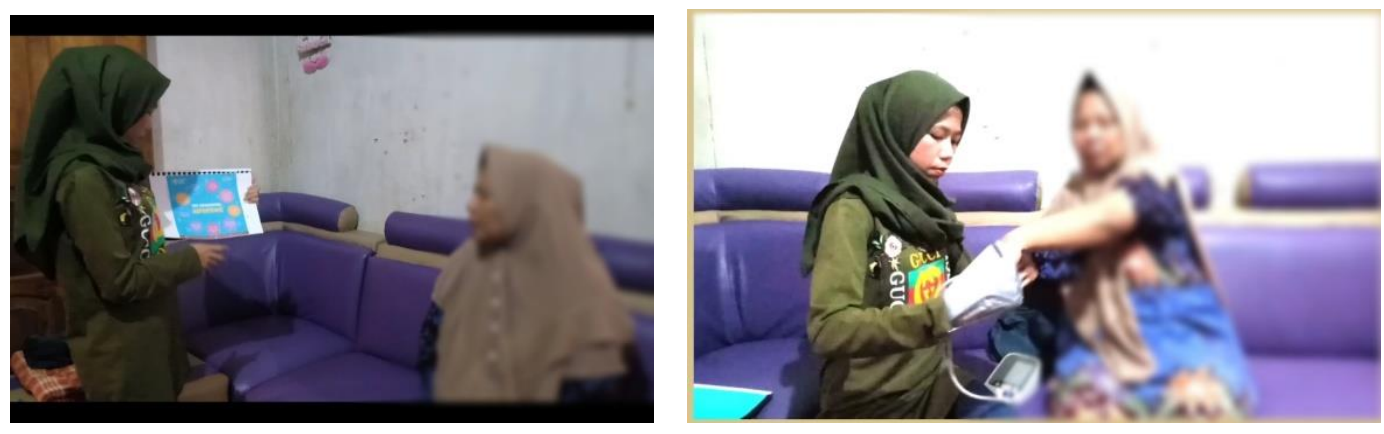


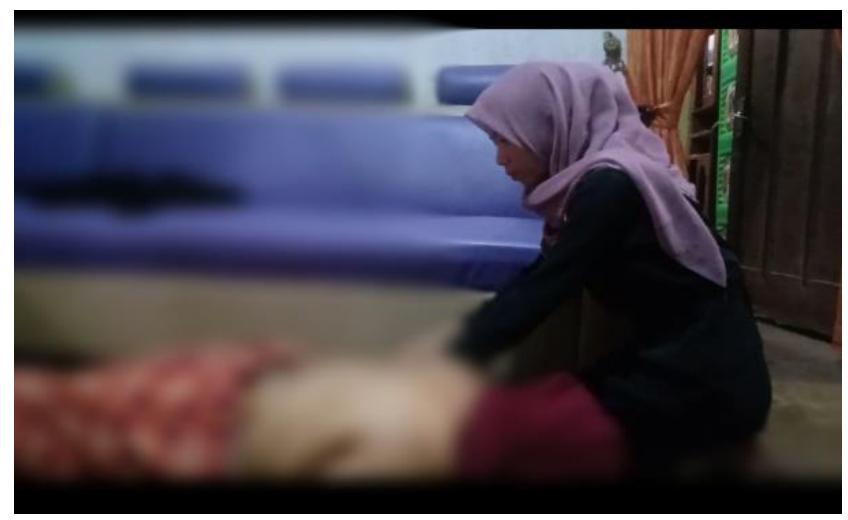

Gambar 4.1 pelaksanaan penyuluhan massage punggung, pengecekan tekanan darah, dan pelaksanaan terapi massage effleurage

\section{KESIMPULAN}

Terapi non farmakologi pemberian massage effleurage terbukti dapat menurunkan tekanan darah pada penderita hipertensi. Hal ini membuktikan beberapa hasil penelitian yang pernah dilakukan kepada klien dengan hipertensi, bahwa pemberian massage effleurage dapat dijadikan alternatif perawatan hipertensi yang murah, mudah, dan aman.

\section{DAFTAR PUSTAKA}

Anies.(2018). Penyakit Degeneratif.Ar-Ruzz Media: Yogyakarta.

Ananto, PD. (2017). Pengaruh Massage Teknik Effleurage Terhadap Tekanan Darah Pada Penderita Hipertensi Di Desa Kalirejo Kabupaten Purworejo.

Dinkes Kota Bandar Lampung.(2019). Kejadian Hipertensi.

Fitriani, D. (2018). Pengaruh Massage Effleurage Terhadap Penurunan Tekanan Darah Pada Penderita Hipertensi Di Wilayah Puskesmas Bakti Jaya Setu Tangerang Selatan.Stikes Widya Dharma Husada Tangerang. Indrayani., M. (2016). Asuhan Persalinan dan bayi Baru Lahir. Jakarta: CV Trans Info.

Kemenkes RI. (2015). Pengertian Hipertensi.

Kemenkes RI. (2019). Kejadian Hipertensi. Jakarta: Indonesia.

Majid, A. (2019). Asuhan Keperawatan Pada Pasien Dengan Gangguan Sistem Kardiovaskular. Pustaka Baru: Yogyakarta.

Manurung, N. (2016). Aplikasi Asuhan Keperawatan Sistem Kardiovaskuler. Trans Info Media: Jakarta.

Maryunani. (2010). Nyeri Dalam Persalinan "Teknik dan Cara Penanganannya". Jakarta, Trans Info Media.

Riskesdas RI. (2018). Kejadian Hipertensi. Jakarta: Indonesia.

Saferi, AW. (2019). KMB 2 Keperawatan Medikal Bedah (Keperawatan Dewasa). Trans Info Media: Jakarta.

Udani. (2017). Pengaruh Massase Pada Penderita Hipertensi Di Uptd Panti Tresna Werdha Lampung Selatan.

Yekti, S. (2020).Cara Jitu Mengatasi Hipertensi.Andi Ofset: Yogyakarta 